\title{
Elinikäinen oppiminen ja matalasti koulutetut ${ }^{1}$
}

\author{
KNUD ILLERIS
}

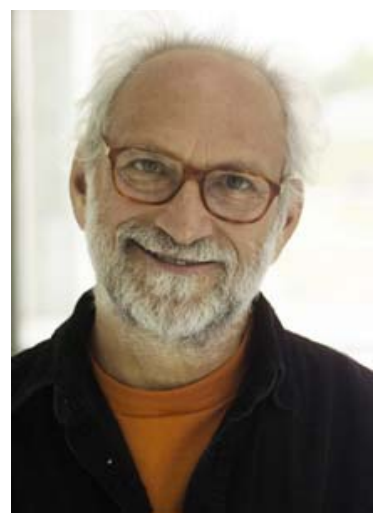

"Ongelmat, jotka on perinteisesti liitetty matalasti koulutettuihin, ovat muuttuneet sekä muodoltaan että sisällöltään kahdenkymmenen vuoden aikana. Kentästä on tullut ongelmallisempi ja kirjavampi, ja se vaatii varsin eriytyneitä, joustavia ja sensitiivisiä avauksia ja palveluita. Tämä puolestaan edellyttää innovatiivista ajattelua, sitoutumista ja joustavuutta poliittisesti, hallinnollisesti ja liike-elämän sektorilla aina huipulta ruohonjuuritasolle asti", kirjoittaa syrjäytymistä työelämästä tutkinut Knud Illeris. ämä artikkeli on syntynyt kolmevuotisen työssä oppimista tutkineen konsortion tuloksena. Konsortiota veti Learning Lab Denmark syyskuusta 2001 vuoden 2004 loppuun saakka http:/ /www.lld.dk/consortia/workplacelearning/en/, IIleris 2003a) ja siihen osallistui 11 vanhempaa tutkijaa ja viisi jatko-opiskelijaa. Siihen sisältyi kuusitoista empiiristä projektia. Projektiraporttien lisäksi julkaistiin neljä kirjaa, useita artikkeleita ja Journal of Workplace Learning -aikakauskirjan teemanumero (Ellström \& Illeris 2004) sekä kokoava kirja aiheesta "Oppiminen työelämässä", joka ilmestyi myös englanninkielisenä painoksena (Illeris et al. 2004).

Yksi konsortion päätavoitteista oli korostaa työvoiman matalasti koulutetun (engl. "low-skilled") osan erityisongelmia suhteessa elinikäiseen oppimiseen. On yleisesti tiedossa, että ne, joilla on jo valmiiksi heikoin koulutustausta, myös osallistuvat järjestettyyn täydennyskoulutukseen vähemmän kuin muut ryhmät. Jatkuvasti tuntuu pätevän se, että mitä enemmän pohjakoulutusta, sitä todennäköisemmin osallistutaan järjestettyyn aikuiskoulutukseen. Luonnollisestikin tämä tekee matalasti koulutetuista entistä haavoittuvampia kaikissa niissä yhteyksissä, joissa koulutustaso on tärkeä, ja siksi he muodostavat hyvin pe- rustavanlaatuisen, vaikean ja vakavan ongelman ajatellen kansainvälistä elinikäisen oppimisen tavoitetta.

Läntisissä teollisuusmaissa tämä ongelma kasvaa kiihtyvällä vauhdilla samalla, kun heikolla koulutuspohjalla suoritettavat työtehtävät vähentyvät. Taustalla on sekä teollisuuden ja tuotannon osuuden suhteellinen väheneminen työmarkkinoilla ja automaation lisääntyminen näissä ammateissa että samanaikaisesti henkilökohtaisten kompetenssien ja tietoteknisten valmiuksien lisääntyvät vaatimukset jatkuvasti kasvavilla aloilla palvelu-, terveys- ja sosiaalialan sektoreilla.

Tämä vähentää matalasti koulutettujen työllistymismahdollisuuksia - ja työttömyysasteen ollessa verrattain korkea alamäkeä vauhdittavat paremmin koulutetut, jotka hakevat koulutustasonsa alapuolelle jääviä työpaikkoja. Koulutuspohjakysymys sekoittuu näin ollen yksilöllisempään kysymykseen siitä, kenellä on oikeanlainen henkilökohtainen kompetenssi.

Hankaluuksia aiheuttaa myös kehityksen suunta siinä, miten uudet sukupolvet suhtautuvat työmarkkinoihin. Suorat, koherentit ja täsmälliset kvalifikaatioprosessit ovat pitkälti antaneet tietä vahvasti yksilöllistyneelle etsiskelylle ja keskey- 
tyville kehityskaarille, joiden kuluessa aloitetaan ja lopetetaan erilaisia koulutusohjelmia, pätkätöille, matkustelulle ja muille työelämään liittymättömille toiminnoille, toimeentulotuki- tai työttömyyskorvausjaksoille, työllistämistuelle ja erityyppisten projektien epämääräiselle sekasotkulle, jota on hyvin vaikea lokeroida vakiintuneisiin kategorioihin ja tilastoihin (vrt. Weil et al. 2005).

\section{Keitä matalasti koulutetut ovat?}

\section{$\mathrm{N}$} äissä olosuhteissa matalan koulutuksen tai taitotason käsite muuttuu hieman sekavaksi ja ongelmalliseksi. Ensin pitäisi pystyä rajaamaan ja määrittelemään, ketkä todellakin kuuluvat tähän ryhmään.

Matalasti koulutetuiksi on yleensä käsitetty tai määritelty kaikki ne, joiden muodollinen koulutus koostuu vain perus- ja keskiasteen koulutuksesta ja mahdollisista lyhyistä kursseista. Mutta jos näkökulmaksi otetaan henkilöiden kriittinen asema sekä yhteiskunnallisen ja työmarkkinoilta syrjäytymisen vaara, nousee esiin kolme hyvin erilaista ryhmää sen lisäksi, että luonnollisestikin esiintyy monia enemmän tai vähemmän yksilöllisiä ja satunnaisia tapauksia.

Ensinnäkin on "klassinen" ryhmä, koulun aikaisin lopettaneet aikuiset, jotka eivät ole hankkineet tai saaneet päätökseen mitään muodollisen pätevyyden tarjoavaa koulutusta. Jotkut heistä pärjäävät oikein hyvin työmarkkinoilla, mutta enemmistö on enemmän tai vähemmän epävarmoissa työolosuhteissa, joissa työttömyys- ja työllisyysjaksot usein vaihtelevat. Jotkut ovat jo aivan työmarkkinoiden rajamailla, ja jotkut ovat menettäneet kokonaan kosketuksen työmarkkinoihin ja joutuneet enemmän tai vähemmän pakolliseen uudelleenkoulutukseen tai saaneet jonkun pysyvän etuisuuden ja syrjäytyneet kokonaan.

Kuitenkin nykyään on myös paljon aikuisia, jotka vahvasta ja arvostetusta koulutuksestaan huolimatta ovat erityisen vaikeassa asemassa, tyypillisesti siksi, että heidän ammattialansa on joutunut radikaalisti vähentämään työvoimaa. Tämä pätee esimerkiksi pankkisektoriin, mutta myös hyvin moniin muihin aloihin. Ja on myös ammatteja, jotka ovat kokonaan hävinneet. Vaikka siis tarkalleen otettuna näitä henkilöitä ei voida määritellä matalasti koulutetuiksi, he ovat joka tapauksessa samassa kriittisessä tilanteessa, kos- ka heidän taidoilleen ei enää ole käyttöä.

Lisäksi on vielä kasvava ryhmä nuoria aikuisia, jotka eivät ole saaneet pysyvää työpaikkaa, vaikka he ovatkin saattaneet hankkia koko joukon usein ei-perinteisiäkin taitoja omia teitään. Heiltä tuntuu kuitenkin puuttuvan vakautta ja tasapainoa ja mahdollisesti muitakin sellaisia sosiaalisia kompetensseja, joita nykypäivänä tarvitaan työpaikan säilyttämiseen.

Luonnollisestikin näiden pääryhmien lisäksi on myös muita, jotka tulee lukea vaikeassa asemassa oleviksi. Heitä ovat esimerkiksi sellaiset henkilöt, jotka ovat kokonaan luopuneet virallisten työmarkkinoiden tavoittelusta ja sinnittelevät eteenpäin etuuksien, matalan kulutustason, julkisten palveluiden ja ehkä ajoittaisten pikkurikosten turvin, sekä sellaiset, joilla on terveydellisiä ongelmia tai jokin vamma.

Näin ollen perinteisesti matalasti koulutettuihin liitetyt ongelmat ovat muuttuneet sekä muodoltaan että sisällöltään kahdenkymmenen vuoden aikana. Kentästä on tullut ongelmallisempi ja kirjavampi, ja se vaatii varsin eriytyneitä, joustavia ja sensitiivisiä avauksia ja palveluita. Tämä puolestaan edellyttää innovatiivista ajattelua, sitoutumista ja joustavuutta poliittisesti, hallinnollisesti ja liike-elämän sektorilla aina huipulta ruohonjuuritasolle asti.

Aiemmin oli nähtävissä selkeä yhteys matalasti koulutettujen sekä työmarkkinoilla vaikeassa asemassa olevien ja siten jonkinlaista erityistukea tarvitsevien välillä. Nyt nämä ryhmät ovat enenevässä määrin kietoutumassa yhteen ja niillä on paljon samanlaisia ongelmia. Lingvistisesti ja faktuaalisesti tästä selvittäisiin puhumalla "haavoittuvista" tai "riskiryhmästä", mutta poliittisesti ja hallinnollisesti on tarvetta selkeille kriteereille, jotka sitten ovat enemmän tai vähemmän vastatusten todellisuuden kanssa.

Näissä olosuhteissa ei liene epäilystäkään siitä, että on olemassa laaja joukko aikuisia, joilla on huomattava yksilöllinen ja sosiaalinen tarve saada henkilökohtaista ja/tai kollektiivista tukea työhön liittyvän harjoittelun tai koulutusohjelmien suorittamiseen. Tämä "haavoittuvien" aikuisten ryhmä on vain osittain samankaltainen kuin se ryhmä, joka voidaan määritellä matalasti koulutetuiksi. Joka tapauksessa aion käyttää tätä termiä jatkossa, koska se on yleisesti käytössä ja edelleenkin pätee merkittävään ryhmään. Teen tämän kuitenkin sillä selkeällä varauksella, että termi on jäämässä pois käytöstä ja vaikka poh- 
dintani ei kata kaikkia matalasti koulutettuja oppijoita, se toisaalta pätee moniin inmisiin, jotka ovat ammattitaitoisia ja/tai koulutettuja, mutta eivät siitä huolimatta ole työmarkkinoiden suosiossa.

\section{Subjektiivinen ambivalenssin tunne}

seimmille tämän ryhmän jäsenille on tyypillistä se, että he ovat subjektiivisesti erittäin kaksijakoisia suhteessa mihin tahansa formaaliin koulutukseen. He samaan aikaan sekä haluavat että eivät halua osallistua. Olemme kollegani kanssa tällaisia henkilöitä sekä työpaikoilla että kouluympäristöissä haastatellessamme havainneet, että yleisesti ottaen he tietävät varsin hyvin tarvitsevansa muodollista koulutusta tai harjoittelua saadakseen pysyvän työpaikan. Samaan aikaan he kuitenkin kovasti toivovat, että näin ei olisi.

Tämän ryhmän muodollisesti epäpätevien tilanne johtuu yleensä huononlaisesta koulumenestyksestä. Yhdeksän tai useamman vuoden ajan he saivat päivittäin todeta, että he eivät ole tarpeeksi hyviä, heitä nöyryytettiin ja marginalisoitiin ja he toivoivat pääsevänsä koulusta eroon mahdollisimman pian. Hyvin harvaa heistä houkuttelee ajatus palaamisesta tilanteeseen, joka muistuttaisi epäonnistumisista ja nöyryytyksistä - ja jossa ne luultavasti jopa toistuisivat. Toisaalta on yhä selvempää, että se on heille ainoa keino selvitä kriittisestä tilanteesta.

Tilanne on hieman erilainen niiden osalta, jotka ovat kyllä ammattitaitoisia tai koulutettuja, mutta epämyyvillä aloilla. Heillä haluttomuus uudelleenkoulutukseen kumpuaa usein vahvasta itsekunnioituksen säilyttämistarpeesta. Tyypillisesti he ovat olleet vuosikausia kunnollisessa ja arvostetussa työssä, jolla he ovat ansainneet elantonsa ja sosiaalisen asemansa. Heille on rakentunut yhteiskunnalle panoksensa antaneen arvokkaan työntekijän ja hyödyllisen kansalaisen identiteetti. Siksi he haluavat puolustaa tätä identiteettiä ja heistä on jotenkin sopimatonta, epäreilua ja infantilisoivaa joutua takaisin kouluun ja oppilaan alempiarvoiseen asemaan. Kuitenkin myös he tietävät, ettei heillä ole muuta mahdollisuutta saada entisenlaista elämäänsä takaisin.

Nuorten työttömien aikuisten (karkeasti jaoteltuna alle 30-vuotiaiden) ambivalenssi on myös jossain määrin erilaista. Heistä ei ole nöyryyttävää palata kouluun, koska he ovat kasvaneet yh- teiskunnassa, joka on jo omistautunut elinikäiselle oppimiselle. He ovat siksi aina tienneet, että se on tavalla tai toisella heidän kohtalonsa. Se ei kuitenkaan tarkoita, että lisäkoulutus olisi heille houkutteleva tulevaisuudennäkymä. Tyypillisesti se on heidän mielestään tylsää, rajoittavaa ja se asettaa heidät ei-toivottuun alempiarvoiseen asemaan. Kuitenkin hekin tietävät, että lisäkoulutus on heidän ainoa mahdollisuutensa (Simonsen 2000).

\section{Hakevan toiminnan ja mahdollisuuksien tarve}

\section{$\infty$} elvästikin työmarkkinoiden erilaisilla matalasti koulutetuilla tai muilla vaikeassa asemassa olevilla ihmisryhmillä on lähes aina selkeä tietoisuus lisäkoulutuksen tarpeesta, erityisesti yleisillä alueilla kuten lukemisessa, kirjallisissa taidoissa, aritmetiikassa ja matematiikassa, vieraissa kielissä, tietoteknisissä taidoissa ja yleisessä sosiaalisessa ja kulttuurisessa suuntautumisessa. Mutta vastakkaiseen suuntaan vetävät voimat koulutukseen liittyvän itseluottamuksen puute ja kouluun palaamisen epämiellyttävyys - ovat yleensä vahvempia. Siksi vaaditaan jokin erityinen kannustin, relevantti avaus, joka vastaa heidän kokemiaan tarpeita ja jollain tavoin vähentää sosiaalisia, rahoituksellisia ja käytännön esteitä sekä erityisesti nöyryytyksen kokemista.

Sellaisilla aikuisilla, joilla on jo ammattikoulutus tai muu pätevöivä koulutus, mutta jotka ovat joutuneet rakennetyöttömyyden uhreiksi ja sen vuoksi sopeutumaan ja uudelleenkouluttautumaan päästääkseen takaisin työmarkkinoille, pääasiallinen psykologinen ongelma on identiteetin puolustaminen. Siksi suurin haaste sekä heille että niille, jotka yrittävät heitä auttaa, on defenssimekanismien voittaminen tai kiertäminen. Niinpä jatko- tai uudelleenkoulutusta on tarjottava ja järjestettävä tavalla, joka kunnioittaa inmisten kolhiintunutta työidentiteettiä samalla, kun uusi identiteetti vähitellen rakentuu. Nykyinen ohjaus- ja koulutusjärjestelmä ei näytä tätä tukevan tai riittävästi ymmärtävän (vrt. IIleris 2003b, 2004a).

Nuoria työttömiä aikuisia leimaa vahvasti jälkimodernin markkinayhteiskunnan laajalle levinnyt individualismi (Beck \& Beck-Gernsheim 2002). Heille on yleensä jatkuvasti tarjottu henkilökohtaisia valintoja kaikilla mahdollisilla alueilla varhaislapsuudesta lähtien. He ajattelevat, 
että kaikilla alueilla on ja pitääkin olla mahdollisuus vapaaseen valintaan ja että on tärkeää, suorastaan koko elämän ydin, tehdä aina vain oikeita valintoja ja siten luoda itsestään sellainen, kuin he itse tahtovat olla. Näin ollen he tyypillisesti aloittavat koulutuksen tai kurssin vain nähdäkseen, voisiko tämä ala "sytyttää" ja täyttää heidän usein pilviä hipovat odotuksensa. He tarvitsevat siis tukea kyetäkseen pitämään kiinni tavoitteestaan, jotta he eivät luovuttaisi heti ensimmäisten ongelmien ilmetessä. Tukeen on joskus myös liityttävä unelmien murskaamista, mikä varovaisesti mutta varmasti auttaa nuoria aikuisia löytämään omat rajansa. Kaikista ei voi tulla rokkitähteä, keskusteluohjelman juontajaa tai designeriä.

Toisilla tässä ryhmässä on vaikeuksia löytää mitään, mikä sytyttäisi tai mistä he voisivat innostua. He eivät kykene täyttämään yhteiskunnan ja opettajien taholta tulevia odotuksia, joiden mukaan heidän pitäisi "tuntea" oma sisäinen motivaationsa. Kuitenkaan he eivät myöskään voi pakottaa itseään hakeutumaan vähiten arvostettuihin töihin esimerkiksi terveydenhuollon tai kaupan alalle.

Erityisesti pojat, ja etenkin vähemmän teollistuneiden yhteiskuntien etnistaustaiset pojat, toivovat yleisimmin pääsevänsä ammattitaitoa edelIyttämättömään käytännön työhön mahdollisimman pian voidakseen alkaa tienata kunnon palkkaa ja välttää loputtomat valinnat, joita he eivät kykene hallitsemaan.

\section{Subjektiivisen ankkuroinnin tarve}

\section{$\mathrm{M}$} atalasti koulutettuja ja muita riskiryhmiä koskevat koulutushankkeet näyttävät muuttuvan yhä vaihtelevammiksi ja epämääräisemmiksi. Jos asiaan aiotaan suhtautua vakavasti eli tehdä muutakin kuin kaunistella tilastoja ja ehkä hoitaa eri ryhmistä muutaman vahvimmilla resursseilla varustetun tilannetta, vaaditaan radikaaleja aloitteita, joiden tulee johdonmukaisesti pitää lähtökohtanaan ja kunnioittaa tilannetta sellaisena, kuin siinä elävät sen kokevat. Paljoakaan ei tule tapahtumaan, jos ne, joiden tulisi oppia, eivät omien edellytystensä pohjalta löydä mielekkyyttä (Illeris 2004a).

Näille ryhmille juuri tämä subjektiivinen ankkurointi on avain sellaisiin toimintoihin ja toimenpiteisiin, joilla voidaan saavuttaa laajempi läpimurto. Mainittujen erilaisten ryhmien jäsenet ovat eri tavoin tilanteissa, joissa he eivät ole suoraan perinteisten koulutushankkeiden saavutettavissa. He eivät todellisuudessa usko näihin hankkeisiin, heillä on huonoja kokemuksia odotusten täyttämisen epäonnistumisesta ja he ovat yleensä toistuvasti kokeneet torjutuksi tulemista, kunnioituksen puutetta jne. Näissä konteksteissa jonkinlainen ankkuri tai tämän psykologisen kokemuksen lähtökohta ja tilanteen tulkinta on välttämättömyys.

Samanaikaisesti relevanteissa hankkeissa on kyse myös eräänlaisesta siirtymästä, sillä ongelmana on nimenomaan nykyinen tilanne ja se, miten yksilö sen kokee. Siten pysyvä ratkaisu edellyttää jonkinlaista läpimurtoa, koulutukseen liittyvää angstia joka on voitettava, identiteetin puolustusta (identiteettidefenssiä) joka on avattava, epärealistisia unelmia jotka on saatava realistiselle tasolle, tai ehkä haaveita ja tavoitteita jotka on löydettävä jostakin suuresta, järjestäytymättömästä tyhjiöstä.

Tällaiset prosessit ulottuvat psykologisesti yleistä koulutuskäsitystä syvemmälle (Illeris 2004b). Useimmissa tapauksissa kompetenssia kehittävät hankkeet ovat kuitenkin paras tapa edetä, koska parempien ja käytännön kannalta oleellisempien kompetenssien kehitys on tärkeä osa tilanteesta selviämistä. On kuitenkin hyväksyttävä sekä poliittisella, hallinnollisella että käytännön tasolla se, että näiden ryhmien relevantti kompetenssikehitys on suoraan kytköksissä eräisiin vaikeisiin ja vaativiin psykologisiin prosesseihin, joita ei voida jättää huomioimatta jos edistystä halutaan saavuttaa.

Tämä ei vaadi vain kyseessä olevan henkilön kokeman tilanteen ymmärtämistä ja kunnioittamista Se vaatii myös hyväksyntää ja samalla lujuutta pitäytyä sosiaalisissa realiteeteissa, kun henkilö kokee oikeutetusti turvattomuutta ja elättelee epärealistisia toiveita. Ketään ei auta kouluttaminen töihin, joissa heille ei ole tarvetta. Mutta jos ihmiset aikovat kouluttautua johonkin, missä heitä tarvitaan, on heidän haluttava sitä itse. Psykologisesti vapauttavat ja sosiaalisesti relevantit kvalifikaatioprosessit pitää liittää yhdeksi käytännön prosessiksi.

Niinpä tämän kahtalaisuuden hallitsevien henkilöiden tulee ottaa vastatakseen näistä toiminnoista. Tällaisia henkilöitä voi olla vaikea löytää. Saattaakin olla välttämätöntä ryhtyä sekä koulutuksellisiin että palkkauksellisiin toimenpiteisiin. Lisäksi tarvitaan aikaa ja relevantteja 
työmarkkinamahdollisuuksia. Kaiken kaikkiaan on hyväksyttävä se, että tällaisilla prosesseilla ei ole laajoja onnistumismahdollisuuksia, ellei kohdehenkilöiden subjektiivisia tarpeita hyväksytä ja olla valmiita investoimaan tarvittavia resursseja. Jokaisen onnistuneen prosessin myötä on kuitenkin toisessa päässä mahdollista säästää paljonkin rahaa, ja entisestä kalliiksi käyvästä ongelmasta saadaan muodostettua pätevää työvoimaa.

Jotta voisimme nujertaa matalasti koulutettujen ja muiden vaikeassa asemassa olevien ryhmien laajan ja mutkikkaan ongelmakimpun, pitää meidän ymmärtää, että minimiratkaisuihin investoiminen ei auta. On mentävä syvemmälle ja otettava psykologinen ulottuvuus vakavasti. Tarvitaan korkeasti koulutettuja inmisiä vastaamaan avaintoiminnoista. On varmistettava, että työmarkkinaosapuolet osallistuvat aktiivisesti ja unohtavat kapeakatseiset intressit. Mukaan on saatava myös relevantteja työpaikkoja, vaikka se joissain tapauksissa saattaakin tarkoittaa taloudellisia hyvityksiä tai muita kannustimia.

Tämä on laaja ja vakava inhimillinen ja sosiaalinen ongelmakenttä. Se on syöksykierre, joka on katkaistava. Puolivillaiset ratkaisut johtavat vain uusiin ja entistä kalliimmiksi käyviin inhimillisiin ja taloudellisiin ongelmiin.

Seuraavassa pyrin lähestymään käytännön ongelmanratkaisulle tärkeitä seikkoja tarkemmin.

\section{Kontaktit ja päänavaus}

$\mathrm{K}$

ten jo mainitsin, suhtautuvat työmarkkinoilla olevat matalasti koulutetut usein skeptisesti kaikkeen, mikä tuo heille mieleen koulun ja opetuksen. Työpaikoillakin ollaan usein haluttomia järjestämään heille erityisiä oppimishankkeita. On siis tarpeen luoda erityisiä hankkeita, jotta saataisiin työpaikat tarjoamaan tälle ryhmälle tilaisuus olla mukana esimerkiksi projekteissa, toiminnasta oppimisessa, oppimissuuntautuneissa verkostoissa sekä työnvaihto- ja työnkierrätysohjelmissa, jotka tarjoavat toisentyyppisiä oppimismahdollisuuksia kuin kouluopetus (Illeris et al. 2004). Niiden avulla kyettäisiin myös järjestämään rahoitusta relevanteille kontakteille sekä koulujen ja koulutuskeskusten oppimiseen kannustavalle toiminnalle.

Samanaikaisesti on ratkaisevan tärkeää esittää avauksia ja kannustimia, jotka ovat suoraan yhteydessä matalasti koulutettujen skeptisismiin ja estoihin koskien yleistä oppimista ja lisäkoulutusta, etenkin sellaisilla alueilla kuin lukeminen, kirjallinen ilmaisu, aritmetiikka ja tietotekniset taidot. Sama koskee työhön liittyvien ja sosiaalisten aineiden yleistä tietoutta.

Ensisijaisesti kyse on kontaktien luomisesta skeptisten työntekijöiden ja työnantajien välille. Kontaktit voivat myötävaikuttaa niiden oppimistarpeiden tematisointiin, joita suurin osa ihmisistä itse asiassa ilmaiseekin alan opintojen yhteydessä. Henkilökohtaisille kontakteille, jotka koetaan lojaaleiksi ja kunnioittaviksi, tuntuu olevan tarvetta, kun taas ulkopuolelta, johtoportaasta tai viranomaisilta tuleviksi koetuilla kontakteilla ei yleensä ole kovin hyviä onnistumismahdollisuuksia.

Kokemus on osoittanut, että parhaat edellytykset tarkoituksenmukaisen vuoropuhelun käynnistämiseen on sellaisella oppimiseen kannustavalla toiminnalla, joka tulee asiasta kiinnostuneiden työtovereiden, ammattiliittojen edustajien, terveys- ja turvallisuusalan edustajien tai itse ruohonjuuritasolla jatkokoulutuksen parissa työskentelevien henkilöiden taholta (Illeris et al. 2004). Tämä kuitenkin vaatii aikaa, sitoutumista ja tietyn määrän kokemusta asian hoitamisesta. Niinpä on oltava resursseja kouluttaa tällaisia kontaktihenkilöitä. On myös oltava tarvittava aika ja tarvittavat käytännön mahdollisuudet.

Saimme erityisen hyviä kokemuksia ja tuloksia eräässä projektissamme, jossa aikuiskouluttajat olivat kontaktissa paikallisissa teollisuusyrityksissä ammattitaidottomien työntekijöiden kanssa. Opimme kuitenkin, että henkilökohtaiset keskustelut työntekijöiden kanssa vaativat kouluttajilta aikaa, etukäteen valmisteltuja relevantteja ehdotuksia ja halua mukauttaa ehdotuksia työntekijöiden tarpeiden mukaan. Tarvitaan myös kontaktitoiminnalle varattua erityistä rahoitusta (Illeris et al. 2004). Jos rahoitus on otettava laitoksen yleisistä toimintakuluista, tuntuu olevan lähes luonnonlaki, ettei se ole riittävä.

\section{Tukea ja neuvontaa,} ei pakkosijoitusta

$M$ onet lisäoppia tarvitsevista matalasti koulutetuista eivät kuitenkaan ole työssäkäyviä. Itse asiassa suurin osa Tanskassa aikuiskoulutukseen osallistuvista on sijoitettu, ohjattu tai lähetetty koulutusohjelmaan viranomaisten tai laitosten toimesta, eikä se ole yleensä ollut positiivinen 
kokemus. Tutkimukseni kuluessa olen ollut suorastaan kauhistunut huomatessani, miten paljon on aikuisopiskelijoita, jotka ovat tunteneet joutuneensa "pakkosijoitetuksi" koulutukseen ja joilla ei ole ollut edes kohtuullista etukäteistietoa kurssin tavoitteista (Illeris 2003b).

Tämän tausta on epäilemättä osittain siinä, että ohjaavat tahot työskentelevät huomattavassa aikapaineessa, ja ohjaajille on asetettu tiukat rajat jokaiseen asiakkaaseen käytettävään aikaan. Siksi he ovat pakotettuja toteamaan tehtävänsä suoritetuksi heti, kun asiakas on hyväksytty johonkin koulutusohjelmaan.

Tilanne on kuitenkin koulutukseen osallistujille kaksinkertaisesti alistava: ensinnäkin heistä tuntuu, että he joutuvat toimimaan pakon tai paineen alaisina jo lähestyessään näitä viranomaisia, ja toisekseen he kokevat, ettei heille osoiteta edes kohtuullista yksilöllistä huomiota. Vaikkakin he useimmissa tapauksissa objektiivisesti ovat tilanteessa, jossa he tarvitsevat koulutusta, he subjektiivisesti kokevat joutuneensa pakotetuiksi ja sijoitetuiksi, ja se on heistä nöyryyttävää ja turhauttavaa.

On päivänselvää, että tällaisessa kontekstissa on varsin sattumanvaraista ja epävarmaa se, lähteekö tarkoituksenmukainen oppiminen kurssilla lainkaan käyntiin. Tilanne muuttuu yhä paradoksaalisemmaksi, jos sitä vertaa kompetenssikehityksen nykyaikaisiin vaatimuksiin. Kaiken lisäksi oppijoiden turhautuminen voi kehittyä vahvaksi koulutusohjelman sisäistä disintegraatiota aiheuttavaksi voimaksi, mikä vuorostaan johtaa kurssin epäonnistumiseen myös niiden opiskelijoiden osalta, jotka olivat aloittaneet positiivisemmin ja keskittyneemmin.

Tämä ei ole hyvä myöskään yhteiskunnan ja kansallisen talouden näkökulmasta. Aktivoitumista tapahtuu vain paperilla (ja tilastoissa). Motivaatio ja henkilökohtainen "koulutuksen hyväksyminen"puuttuvat täysin. Sen sijaan koetaan epävarmuutta, hämmennystä, turhautumista, kiukkua ja muita negatiivisia tunteita. Näin ollen koulutusinstituution resurssien tuhlaus, joka voi olla paljon laajempaakin ja vaikuttaa jopa opettajiin ja muihin opiskelijoihin, kumoaa ohjaajien säästämän ajan. Niin kauan kuin ohjausta tehdään näin, kyse ei ole vain eettisesti erittäin kritisoitavasta hallinnosta, vaan myös taloudellisessa mielessä vakavasta virheestä.

Jotta tässä kontekstissa tapahtuva ohjaus olisi eettisesti perusteltua ja käytännöllistä sekä talo- udellisesti järkevää, on ratkaisevan tärkeää tarjota sitä kunnes kyseessä oleva henkilö "hyväksyy lopputuloksen" psykologisesti. Toisin sanoen hän on käsittänyt ja hyväksynyt sen, että valittu koulutuskurssi on sopiva, ja hän on näin ollen valmis saavuttamaan parhaan mahdollisen tuloksen. Vain silloin on inhimillisesti ja taloudellisesti järkevää aloittaa koulutusohjelma (Illeris 2004a).

Sanottakoon, ettei tavoite ole ollenkaan epärealistinen. Tietysti edellytyksenä on ensinnäkin se, että kussakin tapauksessa voidaan löytää realistinen mahdollisuus. Mutta aivan yhtä tärkeää on tarjota vaativalle ja henkilökohtaiselle sopeutumisprosessille välttämätöntä aikaa ja tukea. Tarvitaan dialogia, jonka lähtökohtana ovat yksilön omat edellytykset. Yksilö itse tarvitsee aikaa pohtiakseen asioita, keskustellakseen niistä luotettaviksi kokemiensa inmisten kanssa, tottuakseen ajatukseen, löytääkseen tilanteen positiiviset näkökohdat ja ennen kaikkea hyväksyäkseen projektiin lähtemisen aktiivisesti ja varauksettomasti.

Tutkimuksessamme olemme havainneet, että vaikka monet olivat hyvin tyytymättömiä prosessiin, eikä sillä heidän mielestään ollut mitään tekemistä ohjauksen kanssa, he kaikesta huolimatta pitivät sen tuloksena tapahtunutta sijoittamistaan kohtuullisen onnistuneena. He kuitenkin kokivat sen nimenomaan sijoittamisena, mikä aiheutti syvää nöyryytystä ja negatiivista asennetta (Illeris 2003b). Kaikki "ohjaaminen" olisi siis mitä ilmeisimmin voitu toteuttaa melko helposti positiivisen valinnan kautta, mikä olisi johtanut henkiseen hyväksyntään. Tämä olisi psykologisesti mahdollistanut aivan toisenlaisen alkuasetelman opetukselle ja täten myös oppimiselle.

\section{Vastuunjaon ratkaiseva tärkeys}

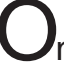
n myös ratkaisevan tärkeää, että suunnittelun lähtökohtana pidetään sitä, että osanottajat ovat aikuisia, jotka sekä muodollisesti että todellisuudessa ovat vastuussa omista teoistaan ja päätöksistään. Tämä koskee tietysti myös heidän oppimistaan ja koulutustaan. Itse asiassa se aikuiskoulutusohjelmien elementti, jota osallistujat kaikkein voimakkaimmin vastustavat, on se, ettei heidän vastuutaan kunnioiteta. Mahdollisesti he eivät kunnioita sitä edes itse. Kunnioituksen puute tuntuu kumpuavan siitä, että meille kaikille on jäänyt mielikuvia opiskelusta omilta 
kouluajoiltamme, jolloin juuri vastuunjako oli erilaista, koska oppilaat olivat lapsia.

Vastuunjakokysymys on olennainen, kun ollaan tekemissä aikuiskoulutuksen kanssa. Kun vastuunjako on sisäistetty, on saavutettu myös avain monien sinänsä irrationaaleilta näyttävien, mutta aikuiskoulutusohjelmiin vaikuttavien asioiden ymmärtämiseen. Nämä vaihtelevat yleisestä suunnittelusta kaikenlaisiin vähäisempiin ja merkittävämpiin käytännön yksityiskohtiin ruohonjuuritasolla. Tähän liittyy myös sen ymmärtäminen, etteivät vain instituutiot ja opettajat "oletusarvoisesti" pakota osanottajia lapsen rooliin viemällä heiltä sen vastuun, joka heille eettisessä, laillisessa, käytännöllisessä ja oppimismielessä kuuluu. Myös osanottajat itse periaatteessa näkevät tämän luonnollisena ja oikeutettuna, vaikka he samaan aikaan enemmän tai vähemmän tietoisesti vastustavat sitä.

Näin ollen kokonaisuus ei ole aivan niin yksinkertainen, että voisimme vain päättää aikuiskoulutuksen tietyissä puitteissa olevan osanottajien vastuulla. Aikuiskoulutusohjelmia hallinnoivien tahojen on aktiivisesti pyrittävä olemaan ottamatta vastuuta, mikä paradoksaalisesti sisältää sen, että heidän on samalla hyväksyttävä vastuu voidakseen "palauttaa" sen osallistujille. Se ei ole aivan niin mutkikasta, kuin miltä se ensin saattaa kuulostaa. Käytännössä se on osoittautunut hyvin vaikeaksi prosessiksi, mihin usein liittyy syvälle juurtuneen vastustuksen kitkeminen. Siten se vaatii sitkeyttä ja päättäväisyyttä sekä opettajilta että osallistujilta.

Opettajien ja vetäjien on aina vaikeaa luovuttaa valta-asemansa vapaaehtoisesti ja vieläpä aktiivisesti. Lisäksi vastuun ottaminen voidakseen olla ottamatta vastuuta tuntuu sekä paradoksaaliselta että epäjohdonmukaiselta. Tämä on kuitenkin juuri sitä, mitä tarvitaan. Tästä tilanteesta aikuiskasvattajat usein löytävät itsensä, ja ammattimaisen aikuiskasvattajan ratkaiseva kriteeri onkin sen hallitseminen. Lisäksi tilanne voi käytännössä olla hyvin herkkä ja emotionaalinen. Vain veteen piirretty viiva erottaa osanottajien oman oppimis- ja kouluttautumisvastuun ja opettajien vastuun oppimisen ja koulutuksen optimaalisista olosuhteista ja panoksesta.

Nykyisessäjärjestelmässä osanottajat voidaan helposti nähdä vastuuttomina vain siksi, että he arkailevat ottaa vastuuta asioista, jotka he pohjimmiltaan kokevat muiden päättäneen heidän puolestaan. Voi hyvin olla, että monissa tapauk- sissa he olisivat päättäneet itse samoin tai lähes samoin, mutta heillä on vain harvoin ollut tähän tilaisuus, koska kulttuuri sanelee sen, että tärkeät päätökset tekee joku muu heidän puolestaan. Voi myös hyvin olla, että heistä on vaikeaa tehdä päätöksiä itse, vaikka heillä olisikin siihen mahdollisuus, mutta loppujen lopuksi juuri siitä kompetenssikehityksessä on paljolti kyse. Tämän vuoksi "järjestelmä" ei saisi reagoida tällaisiin ongelmiin vain ottamalla vastuun itselleen, vaan päinvastoin sen pitäisi muistuttaa osanottajia siitä, että ongelmien ratkominen on heidän omalla vastuullaan.

Se, mitä haen tässä takaa, ei ole millään muotoa helppo tehtävä. Ensinnäkin on tärkeää rakentaa järjestelmää alhaalta ylöspäin niin, että saavutetaan selkeä ja järkevä viitekehys ja laajalti vaihtoehtoja, joista osanottajat itse voivat, yksilöllisesti tai kollektiivisesti, valikoida itselleen sopivia tämän viitekehyksen puitteissa. Toisekseen on tärkeää jatkuvasti varoa, ettei osanottajille kuuluvaa vastuuta viedä, vaikka varsinkin alkuun he usein ovat taipuvaisia välttelemään vastuuta ja sysäämään opettajan takaisin perinteiseen, vastuulliseen opettajanrooliinsa. Kolmanneksi on tärkeää panostaa hyvin suunnitellusti ja fokusoidusti siihen, että osanottajat saadaan sekä ottamaan vastuuta omasta oppimisestaan että ymmärtämään tekevänsä niin - ja ymmärtämään myös miten tärkeää se on.

Se, että osanottajat kantavat vastuun omasta oppimisestaan ei missään nimessä tarkoita sitä, että aikuiskoulutusohjelmien vetäjillä ja ohjaajilla olisi vähemmän vastuuta. Päinvastoin, vetäjien ja opettajien voi olla vastuumielessä jopa entistä vaativampaa jatkuvasti monissa arkipäivän tilanteissa päättää mikä voidaan järkevästi laskea osanottajien omalle vastuulle ja mistä järjestelmän ja opettajien tulee kantaa vastuu, sen sijaan että he vain täyttäisivät perinteisen, vastuullisen opettajanroolinsa, joka on kaikille niin kovin tuttu heidän omilta kouluajoiltaan.

\section{Koulutustoimintojen aika, paikka ja konteksti}

Kun oppimistoimintoja suunnitellaan, on myös tärkeää jatkuvasti pitää mielessä ja kunnioittaa sitä pingottunutta suhdetta, joka monilla matalasti koulutetuilla on kouluun ja koulutustoimintoihin. Erityisesti alussa, sekä fyysisestä että sisällöllisestä näkökulmasta, täytyy kaiken tapah- 
tua mahdollisimman lähellä päivittäistä työtä. Turvallisuutta luo, jos tutut ja luotettavat työtoverit ovat mukana.

Suurissa yrityksissä työskentelevillä on usein mahdollisuus saada sijoitettua koulutustoiminnot työpaikalleen ja joskus myös yhdistettyä ne suoraan tuotantoon tai muihin työtehtäviin liittyvään koulutukseen. Työttömistä koostuvia tai sellaisia kursseja, joilla on lisäksi työssäkäyviä osanottajia, voidaan pitää sekä kouluissa että sopivissa työpaikoissa, jolloin osanottajat pääsevät tutustumaan erilaisiin työympäristöihin.

Yleensäkin on aina tärkeää ottaa huomioon se, että vaikka osanottajat saattavat usein olla varsin ambivalentteja ajan, paikan ja muiden käytännön asioiden suhteen, heillä on kenties hyvinkin vahva ennakkoasenne. On huomattavasti helpompaa hyväksyä kurssin vaatima runsas matkustus ja ajanhukka, jos osallistuu sellaiselle kurssille, jonka on valinnut vapaaehtoisesti ja jopa innostuneena. Meillä Tanskassa on monia esimerkkejä ammattikursseista, joita järjestetään työpaikoilla tai lähellä niitä työpäivän päätteeksi ja joissa tasapuolisesti työnantaja maksaa kurssin ajalta palkkaa ja työntekijät käyttävät siihen vapaa-aikaansa. Se koetaan "reiluksi kaupaksi” ja niinpä se tarjoaa hyvät lähtökohdat ja ilmapiirin oppimiselle.

\section{Oppimissisältöjä ja -metodeja tulee vaihdella}

$\mathrm{O}$ tärkeää vaihdella oppimissisältöjä ja -metodeja runsaasti. Matalasti koulutettujen on usein vaikeaa nähdä työ laajemmassa kontekstissa, huomata, että sitä suoritetaan eri tavoin eri ympäristöissä, ymmärtää mikä laukaisee ja määrää syntyviä muutoksia, saada tilaisuus kysymysten esittämiseen sekä epäilysten ja vastustuksen ilmaisemiseen, päästä itse olemaan aktiivinen suhteessa omaan työtilanteeseensa ja työfunktioonsa esimerkiksi projektien tai muiden vastaavien kautta sekä nähdä, että oma kokemus ja taidot ovat tärkeitä ja niitä voidaan pitää lisäoppimisen lähtökohtana. Tälle ryhmälle voi olla lähes euforinen kokemus huomata, että oppimishankkeet voivatkin olla myös sellaisia, joissa omaa kokemusta voidaan hyödyntää, joissa voidaan itse olla mukana päätöksenteossa ja joissa oma panos ei ole merkityksetöntä.

Eräs tanskalainen esimerkki on suuren sokeritehtaan opetusohjelma, jossa osanottajat priori- soivat "pehmeitä" aineita kuten viestintää, aktiivista kuuntelemista ja valmennusta. Samanaikaisesti osanottajat tyypillisesti painottivat, että vapaus käsitellä heidän omaan päivittäiseen työelämäänsä liittyviä asioita ja ongelmia oli positiivista ja erilaista kuin se, mitä he olivat kouluaikoinaan kokeneet. Se, että "joku vaivautuu tekemään jotain ihan meitä varten" oli erilainen ja yllättävä kokemus, joka vahvisti monien itseluottamusta ja itsetuntoa.

Hyvin usein työntekijöiden koulutustarpeet eivät ole selvästi ja yksiselitteisesti muotoutuneita. Sen paremmin yrityksen kuin työntekijöidenkään tarpeita ei voida vain yksinkertaisesti "löytää". Arvokkaita opetusvaihtoehtoja pikemminkin ilmenee prosessissa, jossa työnjohdon toiveita, työntekijöiden tarpeita ja koulutusinstituution tarjontaa kehitetään ja mukautetaan toisiinsa sopiviksi. Se koetaan usein aikaavieväksi, mutta se tarjoaa vankan pohjan kaikille osapuolille ja on tärkeää myös toteutuksen ja myöhemmän seurannan kannalta (Jørgensen 2004).

Kuitenkin kaikkein tärkeintä matalasti koulutetuille on saavuttaa pätevyys perusasioissa kuten kirjoitus- ja lukutaidossa, vieraissa kielissä ja tietotekniikassa. Sen myös oppijat itse yleensä tiedostavat, mutta näiden aineiden vaatima koulumaisempi opetus on juuri sitä, mitä he enemmän tai vähemmän tietoisesti yrittävät välttää. Niinpä edellä kerrotun esimerkin eräs merkittävä piirre oli se, että osanottajien ensin onnistuttua "murtamaan jään" läheisesti työtilanteeseensa liittyvien projektien kautta, heidän oli myöhemmin helpompaa sulattaa perinteisempiä opetustilanteita ja opiskella koulumaisempia aineita.

Pedagogisella tasolla on tärkeää, että edellä käsitelty vastuunjako käännetään käytännössä todelliseksi osanottajajohtoisuudeksi, toisin sanoen osanottajat kontrolloivat prosessia vuorovaikutuksessa pätevää ja lojaalia apua ja tukea tarjoavien opettajien kanssa. Toinen tärkeä pedagoginen periaate on ongelmaorientaatio eli se, että oppimistoimintojen lähtökohdaksi otetaan laajasti määritellyt temaattiset alueet ja ongelmakentät, joiden käsittelyn osanottajat kokevat tärkeäksi koulutusohjelmiensa tavoitteisiin nähden. Se kasvattaa aktiivisen, relevantin oppimisen mahdollisuuksia. Yleisesti ottaen osanottajajohtoisuus ja ongelmaorientaatio toteutuvat parhaiten sellaisten pedagogisten muotojen kautta kuin tekemällä oppiminen (Yorks et al. 1999) ja projektityö (Illeris 1999, 2004a). 


\section{Seuranta, arviointi ja toteutus}

Ko oulutuskurssien kuluessa ja päätteeksi käytetään säännönmukaisesti yhtä tai useampaa seurantatapaa osanottajien toiminnan ja pätevyyden arvioimiseksi. Tällainen seuranta ja arviointi on perimmäiseltä olemukseltaan sosiaalinen pakko; yhteiskunnan on varmistettava, että ihmisillä on tietyt taidot tiettyjen toimien hoitamiseksi tai jatkokoulutukseen pääsemiseksi. Samanaikaisesti sillä, että pätevyydelleen voi saada muodollisen hyväksynnän, saattaa olla yksilölle hyvinkin suuri merkitys, käytännön tasolla statuksen tähden ja psykologisella tasolla tunnustuksena, joka voi vahvistaa identiteettiä ja luoda itseluottamusta.

On kuitenkin tunnettu tosiasia, että seurannalla ja arvioinnilla voi olla voimakas ja kontrolloiva vaikutus kurssin sujumiseen, samoin sekä osanottajien että opettajien käytökseen ja tietoisuuteen, aivan pienintä yksityiskohtaa myöten. Siksi on tärkeää, että käytännöt ja toimintatavat valitaan huolellisesti ja osanottajien asenteiden ja preferenssien kanssa yhteensopiviksi.

Yleensä tanskalaiset aikuiskoulutukseen osallistujat haluaisivat suoritetuista koulutusohjelmista jonkinlaisen dokumentin, joka ei vain osoittaisi riittävää läsnäoloa kurssilla, vaan myös todistaisi hankitun pätevyyden. Tämän myötä he myös osoittavat halua hyväksyä sen, että kurssille osallistujan pätevyys pitää testata, mutta testauksen suorittamiseen perinteisesti kokeella he suhtautuvat silti erittäin skeptisesti. Monilla matalasti koulutetuilla osanottajilla on tuskallisia muistoja kouluajan kokeista. Heidän mielestään niihin liittyy raskasta ja epäoleellista psykologista painetta, niiden arviointi on epäreilua, liian paljon riippuu tuurista ja sattumasta jne.

Kaikenlaisiin läsnäoloseurantoihin ollaan yleensä hyvin tyytymättömiä, etenkin jos niiden lisäksi on koe tai muu kvalitatiivinen arviointi. Läsnäolon seuranta koetaan tyypillisesti kaikkein ilmeisimpänä lapsen rooliin pakottamisen ja "kouluunpaluuseen" myötäsyntyisesti kuuluvan vallanriiston osoituksena. Aikuiset kykenevät aivan hyvin itse ymmärtämään sen, mihin täytyy osallistua ja mitä ilman voi tulla toimeen. He pystyvät itse ottamaan vastuun toimiensa priorisoinnista ja hankkimaan sen pätevyyden, mikä heidän odotetaankin hankkivan.

Toisaalta osallistujien ei ole helppoa esittää selkeitä vaihtoehtoja seurannalle ja arvioinnille, joka on välttämätöntä, jotta saavutettu kompetenssi voidaan dokumentoida. Hyvin yleisesti ollaan kuitenkin sitä mieltä, että opiskelijoiden kanssa päivittäisessä kontaktissa olevien opettajien tulee suorittaa arviointi, koska huolimatta siitä, että on olemassa sekä hyviä että vähemmän hyviä opettajia, vain heillä on käsitys siitä, mitä opiskelija todella osaa, mihin hän kykenee ja mitä hän ymmärtää. Lisäksi vain erittäin poikkeuksellisissa tapauksissa, joissa painotetaan hyvin spesifejä käytännön taitoja, tarvitaan testejä tai kokeita. Aivan ylivoimaisesti useimmin osallistujat haluavat, että arviointi perustuu päivittäiseen työhön sekä erilaisiin tehtäviin ja projekteihin, jotka muodostavat osan kurssista.

On todellakin aiheellista kunnioittaa näitä mielipiteitä jos lähdetään siitä, että osallistujat ovat vastuullisia aikuisia ja että yleensä kurssien tähtäin on kompetenssikehityksessä. Oppimistermein ilmaistuna tarkoitus on löytää seuranta- ja arviointimalleja, jotka tukevat, sen sijaan että estäisivät, osallistujien itsenäisyyttä, vastuullisuutta, yhteistyötä jne. ja siten myös heidän kompetenssikehitystään.

Perinteisiä seurannan ja arvioinnin muotoja on pidettävä vanhentuneina teollisuusyhteiskunnan heijastumina. Käyttämällä läsnäoloseurantaa ja kokeita osallistujat asetetaan vastakkain voimakkaan vastustajan, "systeemin", kanssa samankaltaisesti kuin teollisessa työllisyydessä. Siinä on kyse mukautumisesta ja alistumisesta ulkoisen vallan vaatimuksille eikä henkilökohtaisen kehityksen ja sen realistisen arvioinnin edistämisestä

Valta-aspektia ei luonnollisestikaan voida eliminoida, mutta ei ole mahdotonta löytää sellaisia muotoja, joissa sillä on vähemmän dominoiva ja aikuisten osanottajien omaa kokemusta enemmän kunnioittava rooli silloinkin, kun he kokevat tietynlaista kahtiajakoisuutta itseohjautuvuustoiveen ja muodollisen hyväksynnän saavuttamistoiveen välillä.

\section{Opettajien tehtävät}

Kuvailtujen kaltaisilla aikuiskoulutuskursseilla opettajien on oltava ammatillisesti ja pedagogisesti päteviä ja lojaaleja, osallistujien oppimisprosesseja helpottavia ja tukevia henkilöitä. Ei ole olemassa mitään tiettyä opettajan roolia, joka täyttäisi tämän vaatimuksen parhaiten. Onkin tärkeintä, että opettajat itse kehittävät itselleen so- 
pivan ammattimaisen ja autenttisen toimintatavan.

Osanottajajohtoisuus ei suinkaan tarkoita sitä, että opettajilla olisi vähemmän työtä tai vastuuta. Avainasemassa on aiemmin kuvatun vastuunjaon ja osanottajajohtoisuuden järjestäminen. Lisäksi on muuan muassa luotava turvallinen ja haastava oppimisympäristö, löydettävä relevantteja toimintotyyppejä ja tarjottava relevanttia syötettä, joka vastaa osallistujien tarpeita ja sopii koulutusohjelmaan. Sen ohella on luotava hedelmällinen yhteisö samalla kun yksittäistä osanottajaa tuetaan sopivin tavoin, tilat ja rutiinit reflektiolle ja refleksiivisyydelle, joilla varmistetaan oppimisen ja kunkin osanottajan kiinnostusten ja taitojen vuorovaikutus. Tämän kaiken tulee tapahtua jatkuvassa vuorovaikutuksessa, ja osanottajat tulee itse kontrolloida omia oppimisprosessejaan.

Erityisesti kun ollaan tekemisissä matalasti koulutettujen ja muiden riskiryhmiin kuuluvien oppijoiden kanssa, ovat opettajan tehtävät huomattavasti perinteistä opetuskäsitettä laajemmat. En pohdi tätä enempää, sillä monia niistä on jo sivuttu epäsuorasti. Viimeisenä lähdeviitteenä esitän "tulkitsevan ammattilaisen" käsitteen (Wildemeersch 2000).

\section{Lähteet}

Beck, Ulrich - Beck-Gernsheim, Elizabeth (2002). Individualization: Institutionalized Individualism and its Social and Political Consequences. London: SAGE.

Ellström, Per-Erik - Illeris, Knud (toim.). Workplace learning - Scandinavian perspectives. Journal of Workplace Learning, erikoisnumero, 16 (8).

Illeris, Knud (1998). Adult learning and responsibility. Teoksessa Knud Illeris (toim.): Adult Education in a Transforming Society. Copenhagen: Roskilde University Press.

Illeris, Knud (1999). Project work in university studies: background and current issues. Teoksessa Henning Salling Olesen \& Jens Højgaard Jensen (toim.): Project Studies. Copenhagen: Roskilde University Press.

Illeris, Knud (2003a). Workplace learning and learning theory. Journal of Workplace Learning, 15 (4), 167-178.

Illeris, Knud (2003b). Adult education as experienced by the learners. International Journal of Lifelong Education, 22 (1), s. 13-23.

Illeris, Knud (2003c). Low Skilled Adults' Motivation for Learning.

Elinikäisen oppimisen konferenssissa CEDEFOP:ssa Thessalonikissa 2.-3. kesäkuuta esitetty essee.

(http://www.ruc.dk/inst10/om_inst10/personale/VIP/ki/in_english/publications)

Illeris, Knud (2004a). Adult Education and Adult Learning. Melbourne, Florida: Krieger Publishing Company.

Illeris, Knud (2004b). Transformative learning in the perspective of a comprehensive learning theory. Journal of Transformative Education, 2 (2), s. 79-89

Illeris, Knud et al. (2004). Learning in Working Life. Copenhagen: Roskilde University Press.

Jørgensen, Christian Helms (2004). Connecting work and education: should learning be useful, correct or meaningful? Journal of Workplace Learning, 16 (8), s. 455-465

Simonsen, Birgitte (2000). New young people, new forms of consciousness, new educational methods. Teoksessa Knud Illeris (toim.): Adult Education in the Perspective of the Learners. Copenhagen: Roskilde University Press.

Weil, Susan -Wildemeersch, Danny-Jansen, Theo (2005). Unemployed Youth and Social Exclusion in Europe: Learning from Inclusion? Aldershot: Ashgate.

Wildemeersch, Danny (2000). Lifelong learning and the significance of the interpretive professional. Teoksessa Knud Illeris (toim.): Adult Education in the Perspective of the Learners. Copenhagen: Roskilde University Press.

Yorks, Lyle - O'Neill, Judy - Marsick, Victoria J. (1999). Action Learning - Successful Strategies for Individual, Team and Organizational Development. Baton Rouge: Academy of Human Resource Development.

\section{Viite}

Artikkeli perustuu At the Margins of Adult Education, Work and Civil Society -konferenssissa Joensuun yliopistossa 19.-22.5. 2005 pidettyyn alustukseen. Käännöksen on tehnyt Minna Lumirae. Aikuiskasvatus-lehti esittää artikkelin johdosta kiitoksen konferenssin järjestäjille. 